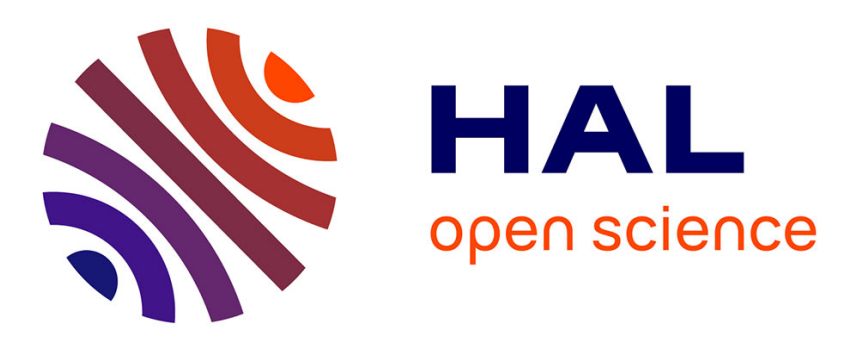

\title{
Three new combinations and one lectotypification of fern and lycophyte taxa from the French overseas territories
}

Germinal Rouhan, Vincent Boullet, Ashley Field, Eric Schuettpelz

\section{To cite this version:}

Germinal Rouhan, Vincent Boullet, Ashley Field, Eric Schuettpelz. Three new combinations and one lectotypification of fern and lycophyte taxa from the French overseas territories. Phytotaxa, 2021, 497 (1), pp.54-56. 10.11646/phytotaxa.497.1.6 . mnhn-03201065

\section{HAL Id: mnhn-03201065}

\section{https://hal-mnhn.archives-ouvertes.fr/mnhn-03201065}

Submitted on 19 Apr 2021

HAL is a multi-disciplinary open access archive for the deposit and dissemination of scientific research documents, whether they are published or not. The documents may come from teaching and research institutions in France or abroad, or from public or private research centers.
L'archive ouverte pluridisciplinaire HAL, est destinée au dépôt et à la diffusion de documents scientifiques de niveau recherche, publiés ou non, émanant des établissements d'enseignement et de recherche français ou étrangers, des laboratoires publics ou privés. 
Three new combinations and one lectotypification of fern and lycophyte taxa from the French overseas territories

\section{GERMINAL ROUHAN ${ }^{1, *}$, VINCENT BOULLET ${ }^{2,3}$, ASHLEY FIELD $^{4,5}$ \& ERIC SCHUETTPELZ ${ }^{6}$}

${ }^{1}$ Institut de Systématique, Évolution, Biodiversité (ISYEB), Muséum national d'Histoire naturelle, Sorbonne Université, École Pratique des Hautes Études, CNRS, Université des Antilles; CP 39, 57 rue Cuvier, 75005 Paris, France; germinal.rouhan@mnhn.fr; https://orcid.org/0000-0002-0751-5352

${ }^{2}$ Conservatoire Botanique National de Mascarin, 2 rue du Père Georges, Les Colimaçons, 97436 Saint-Leu, La Réunion; France; v.boullet43@orange.fr; https://orcid.org/0000-00023482-1662

${ }^{3}$ EA 7462 Géoarchitecture, Université de Bretagne Occidentale, 29200 Brest.

${ }^{4}$ Queensland Herbarium, Department of Environment and Science, Brisbane Botanic Gardens, Mount Coot-tha, Mt Coot-tha Road Toowong, Qld 4066, Australia; ashley.field@jcu.edu.au; https://orcid.org/0000-0002-0139-7914 ${ }^{5}$ Australian Tropical Herbarium, Sir Robert Norman Building, James Cook University Campus, Smithfield Queensland 4878, P.O.Box 6811 Cairns, Qld 4870, Australia.

${ }^{6}$ Department of Botany, National Museum of Natural History, Smithsonian Institution, Washington, DC, U.S.A.; SchuettpelzE@ si.edu; https://orcid.org/0000-0003-3891-9904 *Corresponding author

With the exception of French Guiana and Adélie Land, the French Overseas Territories (FOTs) are islands and their biodiversity is remarkable in many ways. Notably, they harbour numerous unique taxa leading to exceptionally high rates of endemism. Among French endemic plants, 95\% occur in the FOTs, accounting for ca. 4000 species of tracheophytes and 'bryophytes' (Gargominy et al. 2020).

We recently initiated a project entitled "Flore Endémique des Territoires d'Outre-Mer" (i.e., Endemic Flora of the French Overseas Territories; FEnTOM) to summarize the present state of knowledge of plant endemism in the FOTs. Using the most current information and data, we intend to build an up-to-date checklist of all known strict and regional endemic spermatophytes, 'pteridophytes' and 'bryophytes' known in the FOTs (Veron et al. in prep.). In compiling this list, we discovered that three nomenclatural combinations remain outstanding for ferns and lycophytes, and we here present them to avoid the use of invalid combinations in the FEnTOM project and to also make appropriate names available in the French national taxonomic database TAXREF (Gargominy et al. 2020), as well as international taxonomic databases. These new combinations are consistent with the classification presented in PPG I (2016).

Antrophyopsis gigantea (Bory) Rouhan, Boullet \& Schuettp., comb. nov.

Basionym: Antrophyum giganteum Bory (1833: 36)

Type:- Mauritius. Le Pouce, C. Bélanger s.n. (lectotype P [P00483382!], hic designatus; isolectotypes P [P00483381!], P [P01482666!]).

Notes:- This species was not included in the study of vittarioid ferns by Schuettpelz et al. (2016) and its placement in the phylogeny has yet to be assessed. Nonetheless, it is morphologically most similar to Antrophyopsis boryana (Willdenow 1810: 128) Schuettpelz (2016: 717) that was included in the molecular analysis and confirmed as belonging to 
Antrophyopsis (Benedict 1907: 447) Schuettpelz (2016: 717). It is distinguished from A. boryana by sessile, subelliptic to suboblanceolate fronds, but both share the generic characters, notably spherical apical cells of the soral paraphyses and ecostate laminae (i.e. lacking midribs). Although A. gigantea was described from Mauritius, it was never observed there again (Badré 2008) and is today known only from La Reunion. As there are three sheets housed at $\mathrm{P}$, we designated as lectotype the sheet with complete leaves given that the base of fronds is critical for distinguishing the species; also, the same sheet bears the more complete labels.

Lepisorus mucronatus (Fée 1852: 82) Li Wang (2010: 35) var. durus (Copel.) Rouhan, comb. nov.

Basionym: Hymenolepis dura Copeland (1938: 69, t.20).

Synonym: Belvisia mucronata (Fée 1852: 82) Copeland (1947: 192) var. dura (Copel.) Hovenkamp \& Franken (1993: 523).

Type:-French Polynesia: “Australes”, Rapa, versant sud du Mont Lekie, 330 m, 20 July 1934, H. St. John \& J. Maireau 15621 (holotype BISH [BISH1000333, online image]; isotypes BISH [BISH1000335, online image], BO, K [K000880383!], MICH [1191320, online image], P [P00717795!], UC [UC 542661, online image], US [00134710, online image], W).

Notes:- Belvisia Mirbel (1803: 65) is entirely subsumed in Lepisorus (Smith 1846: 13) Ching (1933: 47, 56) following studies by Wang et al. (2010). The variety durus is known from Rapa Island in French Polynesia.

Phlegmariurus pseudovarius (Brownlie) Rouhan \& A.R.Field, comb. nov. Basionym: Lycopodium pseudovarium Brownlie (1969: 23, t.1, f.13-15). Synonym: Huperzia pseudovaria (Brownlie) Holub (1991: 93).

Type:- New Caledonia. Prov. Sud: Mont Humboldt, 1200 m, February 1872, B. Balansa 3558 (holotype P [P00523013!]).

Notes:- Following the classification proposed by Field et al. (2016) and later retained by PPG I (2016), this species formerly placed in Huperzia Bernhardi (1801: 126) belongs in Phlegmariurus Holub (1964: 21). It is endemic to New Caledonia, but may possibly also occur in French Polynesia according to recent observations (J. Nitta, pers. com.).

The type at $\mathrm{P}$ was determined in 2015 by A. Field as Phlegmariurus varius (Brown 1810: 165) A.R.Field \& Bostock (2013: 49) due to the lack of the combination P. pseudovarius, and because he thought it may be a synonym of Phlegmariurus varius. More recent work provides evidence supporting $P$. pseudovarius as distinct, along with at least two other species in this complex (Field, unpublished data).

\section{Acknowledgements}

We thank the Office Français de la Biodiversité (French Agency of Biodiversity) and the Ministère des Outre-mer (French Ministry of Overseas Territories) for funding and supporting this project.

We are also grateful to RECOLNAT national Research Infrastructure (ANR-11-INBS-0004).

\section{References}


Badré, F. (2008) Ptéridophytes 1. Psilotacées à 26. Marsiléacées. In: Bosser, J., Badré, F. \& Guého, J. (eds.) Flore des Mascareignes - La Réunion, Maurice, Rodrigues. IRD, MSIRI, RBG-Kew, Paris. 454 pp.

Benedict, R.C. (1907) The genus Antrophyum-I. Synopsis of subgenera, and the American species. Bulletin of the Torrey Botanical Club 34(9): 445-458. http://dx.doi.org/10.2307/2479065

Bernhardi, J.J. (1801) Tentamen alterum filices in genera redigenda. Journal für die Botanik (Schrader) 1800: 121-136.

Bory de Saint-Vincent, J.B.G.M. (1833) In: Bélanger, C., Bory de Saint-Vincent, J.B.G.M. \& Montagne, C. (eds.) Voyages aux Indes-Orientales par le nord de l'Europe : les provinces du Caucase, la Géorgie, l'Arménie et la Perse, suivi de détails topographiques, statistiques et autres sur les Pégot, les iles de Java, de Maurice et de Bourbon, sur le Cap-De-Bonne-Espérance et Sainte-Hélène ; pendant les années 1825 1829, Botanique II. Paris. 192 pp.

Brown, R. (1810) Prodromus Florae Novae Hollandiae et Insulae van-Diemen, exhibens characteres plantarum quas annis 1802-1805 per oras utriusque insulae collegit et descripsit Robertus Brown; insertis passim aliis speciebus auctori hucusque cognitis, seu evulgatis, seu ineditis praesertim Banksianis, in primo itinere navarchi Cook detectis, 1. J. Johnson \& Co., London. 590 pp.

Brownlie, G. (1969) N³ Ptéridophytes. In: Aubréville, A. (ed.), Flore de la NouvelleCalédonie et Dépendances. Muséum national d'Histoire naturelle, Paris. 308 pp.

Ching, R.-C. (1933) The studies of Chinese ferns IX. Bulletin of the Fan Memorial Institute of Biology 4(3): 47-110.

Copeland, E.B. (1938) Ferns of southeastern Polynesia. Occasional Papers of Bernice Pauahi Bishop Museum of Polynesian Ethnology and Natural History 14(5): 45-101.

Copeland, E.B. (1947) Genera Filicum: the genera of ferns. Chronica Botanica Company of Waltham, Mass. 247 pp.

Fée, A.L.A. (1850-1852) Mémoires sur les Familles des Fougères; Cinquieme Mémoire, Genera Filicum. Paris, Strasbourg, 387 pp.

Field, A. \& Bostock, P. (2013) New and existing combinations in Palaeotropical

Phlegmariurus (Lycopodiaceae) and lectotypification of the type species Phlegmariurus phlegmaria (L.) T.Sen \& U.Sen. PhytoKeys 20: 33-51.

https://doi.org/10.3897/phytokeys.20.4007

Field, A.R., Testo, W., Bostock, P.D.B., Holtum, J.A.M. \& Waycott, M. (2016) Molecular phylogenetics and the morphology of the Lycopodiaceae subfamily Huperzioideae supports three genera: Huperzia, Phlegmariurus and Phylloglossum. Molecular Phylogenetics and Evolution 94: 635-657. https://doi.org/10.1016/j.ympev.2015.09.024

Gargominy, O., Tercerie, S., Régnier, C., Dupont, P., Daszkiewicz, P., Léotard, G., Antonetti, P., Ramage, T., Vandel, E., Petitteville, M., Leblond, S., Idczak, L., Boullet, V., Denys, G., De Massary, J.C., Lévêque, A., Jourdan, H., Rome, Q., Dusoulier, F., Touroult, J., Savouré-Soubelet, A., Barbut, J., Canard, A., Simian, G., Le Divelec, R., Haffner, P., Meyer, C., Van Es, J., Poncet, R., Demerges, D., Mehran, B., Horellou, A., Moulin, N., Ah-Peng, C., Bernard, J.-F., Caesar, M., Comolet-Tirman, J., Courtecuisse, R., Delfosse, E., Dewynter, M., Hugonnot, V., Kondratyeva, A., Lavocat Bernard, E., Lebouvier, M., Lebreton, E., Malécot, V., Moreau, P.A., Muller, S., Noblecourt, T., Pellens, R., Robbert Gradstein, S., Rodrigues, C., Rouhan, G. \& Véron, S. (2020) TAXREF v14.0, référentiel taxonomique pour la France. UMS PatriNat, Muséum national d'Histoire naturelle, Paris. Archive de téléchargement contenant 8 fichiers. 
Available from:

https://inpn.mnhn.fr/telechargement/referentielEspece/taxref/14.0/menu/ (accessed 28 Feb. 2021)

Holub, J. (1964) Lycopodiella, novy rod radu Lycopodiales. Preslia 36: 16-22.

Holub, J. (1991) Some taxonomic changes within Lycopodiales. Folia Geobotanica \& Phytotaxonomica 26(1): 81-94. https://doi.org/10.1007/BF02912943

Hovenkamp, P.H. \& Franken, N.A.P. 1993. An account of the fern genus Belvisia Mirbel (Polypodiaceae). Blumea: Biodiversity, Evolution and Biogeography of Plants 37(2): 511-527.

Mirbel, C.F.B. de (1803) Histoire naturelle générale et particulière des plantes 4. Paris, 431 pp.

PPG I (2016) A community-derived classification for extant lycophytes and ferns: PPG I. Journal of Systematics and Evolution 54: 563-603. https://doi.org/10.1111/jse.12229

Schuettpelz, E., Chen, S.-W., Kessler, M., Pinson, J.B., Johnson, G., Davila, A., Cochran, A.T., Huiet, L. \& Pryer, K.M. (2016) A revised generic classification of vittarioid ferns (Pteridaceae) based on molecular, micromorphological, and geographic data. Taxon 65(4): 708-722. http://dx.doi.org/10.12705/654.2

Smith, J. (1846) Additions to the "Hortus Kewensis". Botanical Magazine 72 (Comp.): 1-42.

Veron, S., Rodrigues-Vaz, C., Lebreton, E., Ah-Peng, C., Boullet, V., Chevillotte, H., Gradstein, S.R., Jérémie, J., Lavocat Bernard, E., Lebouvier, M., Meyer, J.-Y., Munzinger, J., Poncy, O., Thouvenot, L., Viscardi, G., Léotard, G., Gargominy, O., Leblond, S., Pignal, M., Rouhan, G., Tercerie, S., Invernon, V. \& Muller, S. (accepted). Biodiversity and Conservation.

Wang, L, Wu, Z.Q., Xiang, Q.P., Heinrichs, J., Schneider, H. \& Zhang, X.C. (2010) A molecular phylogeny and a revised classification of tribe Lepisoreae (Polypodiaceae) based on an analysis of four plastid DNA regions. Botanical Journal of the Linnean Society 162: 28-38.

Willdenow, C.L. (1810) Species Plantarum. Editio Quarta, 5. Berolini [Berlin], 542 pp. 